\title{
Supervisory Support, Organizational Justice and Perceived Organizational Support: A Review and Research Agenda
}

\author{
Choong Yuen Onn, Tan Luen Peng, Choe Kum Lung* \\ Universiti Tunku Abdul Rahman, Malaysia \\ *choekl@utar.edu.my
}

\begin{abstract}
Past studies have confirmed the relationship between organizational justice and supervisory support with perceived organizational support. However, there is lack of research study conducted on examining the relationship of these two dimensions specifically on the academic staff in Malaysian universities. Furthermore, some researchers also found that organizational support and supervisory support are strongly related to perceived organizational support. Hence, the purpose of this conceptual paper is to provide a review and an examination on the relationship of organizational justice and supervisory support on perceived organizational support among academic staff in Malaysian universities. Conceptual framework and hypotheses have been formulated. The target population is academic staff of Malaysian universities. A simple statistical analysis has been conducted such as reliability analysis and descriptive analysis.
\end{abstract}

Keywords: Perceived Organizational Support, Supervisory Support, Organizational Justice, Procedural Justice, Distributive Justice

\section{Introduction}

In decades, researchers and business practitioners have emphasized the importance of perceived organizational support (POS) in beauty and cosmetics, insurance (Allen, Shore \& Griffeth, 2003), and metal fabricating industries (Wayne, Shore, Bommer \& Tetrick, 2002) in the United States. Likewise, in Asia, P0S is also envisaged as a salient guise in different industries such as legal industries in Hong Kong (Loi, Ngo \& Foley, 2006), and knowledge-intensive industries (i.e. finance, education, engineering and information technology) in Malaysia (Tan, 2008). Substantial studies have empirically identified various antecedents that are significantly related to POS such as supervisory support (Shanock \& Eisenberger, 2006; Rhoades \& Eisenberger, 2002), participation in decision making and growth opportunity (Allen, Shore \& Griffeth, 2003), organizational rewards and job conditions (Rhoades \& Eisenberger, 2002), career development practices (Tan, 2008), fairness of treatment or organizational justice (Loi, Ngo \& Foley, 2006; Rhoades \& Eisenberger, 2002), human resource practices (Nasurdin, Hemdi \& Lye, 2008; Allen, Shore \& Griffeth, 2003) and personality (Rhoades \& Eisenberger, 2002; Aquino \& Griffeth, 1999).

However, there is lack of empirical studies examined the relationship between organizational justice and supervisory support with POS among the academic staff of Malaysian universities. Loi, Ngo and Foley (2006) revealed that procedural and distributive justices significant predict POS in their studies, but, only a few studies have been conducted on this relationship. Besides, supervisory support is an important antecedent of POS. According to Rhoades and Eisenberger (2002), Organizational justice and supervisory support are significant predictors of POS. Hence, two independent variables namely organizational justice and supervisory support are included in this study in attempt to extent the knowledge of POS. In addition, POS plays a critical role in organizations particularly for different level of managers and supervisors to build trust among employees thru giving support, valuing employee's contribution and dedication, as well as putting great cares about employees' well-being. There is a great deal of empirical evidence indicated that POS is associated with different outcomes which will benefit organizations such as reduce turnover intention (Loi, Ngo \& Foley, 2006; Allen, Shore \& Griffeth, 2003), increase organizational and affective commitment (Dawley, Andrews \& Bucklew, 2007; Currie \& Dollery, 2006; Loi, Ngo \& Foley, 2006; Wayne, Shore, Bommer \& Tetrick, 2002), increase job satisfaction (Allen, Shore \& Griffeth, 2003) and enhance organizational performance (Byrne \& Hochwarter, 2007). Therefore, the objective for this study is to examine the relationship between the antecedents (organizational justice and supervisory support) with POS. 
Perceived Organizational Support: Organizational Support Theorists (Eisenberger, Cummings, Armeli \& Lynch, 1997; Eisenberger, Huntington, Hutchison \& Sowa, 1986) suggest that employees in organizations form general perceptions toward the organizations by valuing their contributions and cares about their wellbeings. The nature of relationship between employer and employee is reciprocal. From the notion of reciprocity, employees tend to respond positively to favorable treatments from the employers. According to social exchange theory, reciprocity is important in obligating people to respond positively to favorable treatment received from others (Gouldner, 1960). According to Eisenberger, Huntington, Hutchison and Sowa (1986) through the process of personification, employees exert their human characteristics into their works and such actions are beneficial to the organization. On the other hand, employees tend to perceive that organizational support exists when the rewards that they received are based on the decisions of the organization rather than external limitations that beyond the control of the organizations (Eisenberger, Cummings, Armeli \& Lynch, 1997).

Organizational Justice: The concept of organizational justice and organizational justice are found to be popular in organizational settings (Lambert, Hogan \& Griffin, 2007). These two paramount concepts are envisaged as important factors to most employees in organizations (Folger \& Cropanzano, 1998). These two concepts are often called as organizational justice. Organizational justice is defined as employees' general perceptions toward the level of fairness of treatment received inside an organization (Greenberg, 1987). On the other hand, organizational justice can be further divided into distributive justice and procedural justice. Distributive justice is defined as "perceived fairness in outcomes we receive relative to our contributions versus the outcomes and contributions of others" (McShane \& Von Glinow, 2010, p. 151). Employees tend to compare their input and outcome ratios among one another (McShane \& Von Glinow, 2010). When there is an unequal input and outcome ratio between employee and the referent other, the employee will perceived the sense of unfair treatment by the organization. For procedural justice, it is defined as "perceived fairness of the procedures used to decide the distribution of resources" (McShane \& Von Glinow, 2010). Procedural justice emphasizes the mean rather than the end (Lambert, 2003). Employees are more interested in the process of making a fair, consistent and transparent decision (Folger \& Cropanzano, 1998).

Supervisory Support: Eisenberger et al. (2002) define supervisory support as the degree to which employees form impressions that their supervisors care about their interest and well-being, value their efforts and contributions and are supportive with encouragement. The immediate supervisor is playing a critical role in organizations. The encouragement and support from immediate supervisor are deemed to be important as past studies revealed that they are closest to the employee. Therefore, immediate supervisor is able to effectively managing their own respective subordinate's emotions (Dawley, Andrews \& Bucklew, 2008).

Organizational Justice and Perceived Organizational Support: Consistent results have been generated by some studies indicated that organizational justice is significantly associated with POS (Rhoades \& Eisenberger, 2002; Wayne, Shore, Bommer \& Tetrick, 2002; Shore \& Shore, 1995). Shore and Shore (1995) claim that trust will be formed and built when employees perceive the sense of fairness existed with the employers. Both types of justice are contributed to POS (Shore \& Shore, 1995). These two justice dimensions are considered to be distinct constructs and explained unique variance in POS when the other justice dimension was controlled for (Colquitt, Conlon, Wesson, Porter \& Ng, 2001). Greenberg (1990) has posited that distributive justice fail to address an employee's fair procedure pursuit. While, procedural justice is important for social exchange between employees and organizations. This is also supported by another study conducted by Shore and Shore (1995). Shore and Shore (1995) have indicated that repeated instances of resources distribution decision will have a strong cumulative effect on POS. Organizations should allow their employees to have the freedom to voice in decision making procedure of distribution in order to signify the organization's concern their employees' welfare and care for their employees' fairness.

On the other hand, Pillai, Williams and Tan (2001) revealed that employers in Hong Kong have higher discretion over reward allocation. Procedural justice was strongly related to POS as compared to procedural justice. This is due to Hong Kong is a high power distance country which accepts unequal power distribution between managers and employees. For those countries having a high power distance culture, legitimate power is more likely to be existed in the workplace. Managers will play a dominant role in the workplace, 
especially in distributing both economic and socio-emotional benefits. Although, several past studies have confirmed that procedural justice is more important than distributive justice toward POS, but distributive justice is also closely associated with POS (Ambrose \& Schminke, 2003). There are studies which have examined and showed that both procedural justice and distributive justice are important for the development of trust (Loi, Ngo \& Foley, 2006; Cropanzano, Prehar \& Chen, 2002; Wayne, Shore, Bommer \& Tetrick, 2002). Rhoades and Eisenberger (2002) also found that procedural and distributive justices have significantly and approximately equal relationship with POS. Therefore, the proposed hypotheses are formulated as below:

Hypothesis 1: Organizational justice is significantly related to perceived organizational support.

Hypothesis 2: Procedural justice is significantly related to perceived organizational support.

Hypothesis 3: Distributive justice is significantly related to perceived organizational support.

Supervisory Support and Perceived Organizational Support: Supervisory has the responsibility to provide guidance and clear direction to their subordinates. They also have the rights to appraise their employees on their annual performance as they are the one has the closest organizational link to their subordinates. Several past studies have confirmed that supervisory support is positively related to POS (Dawley, Andrews \& Bucklew, 2008; Rhoades \& Eisenberger, 2002). Rhoades, Eisenberger and Armeli (2001) and Eisenberger et al. (2002) have generated the same result. They found that supervisory support is an antecedent to POS. Hence, a proposed hypothesis is formulated as below:

Hypothesis 4: Supervisory support is significantly related to perceived organizational support.

Organizational Justice and Supervisory Support to Perceived Organizational Support: Rhoades and Eisenberger (2002) have postulated that organizational justice and supervisory support are the most significant predictors of POS. Eisenberger et al. (2002) and Dawley, Andrews and Bucklew (2008) supported that the importance of ensuring organizational practices are fair and justice. At the same time, the immediate supervisors also act in pivotal role to provide the support and encouragement to their subordinates. Hence, another proposed hypothesis is formulated as below:

Hypothesis 5: Organizational Justice and Supervisory Support significantly explain the variances of Perceived Organizational Support Model.

\section{Proposed Conceptual Framework}

Based on the discussion presented in the literature review, a conceptual framework has been proposed to examine the relationship between antecedents and POS among academic staff in Malaysian private universities. This study aims to explore the hypothesized effects of supervisory support and fairness of treatment on POS. The proposed conceptual framework is presented below (Figure 1):

Figure 1: The Proposed Conceptual Framework

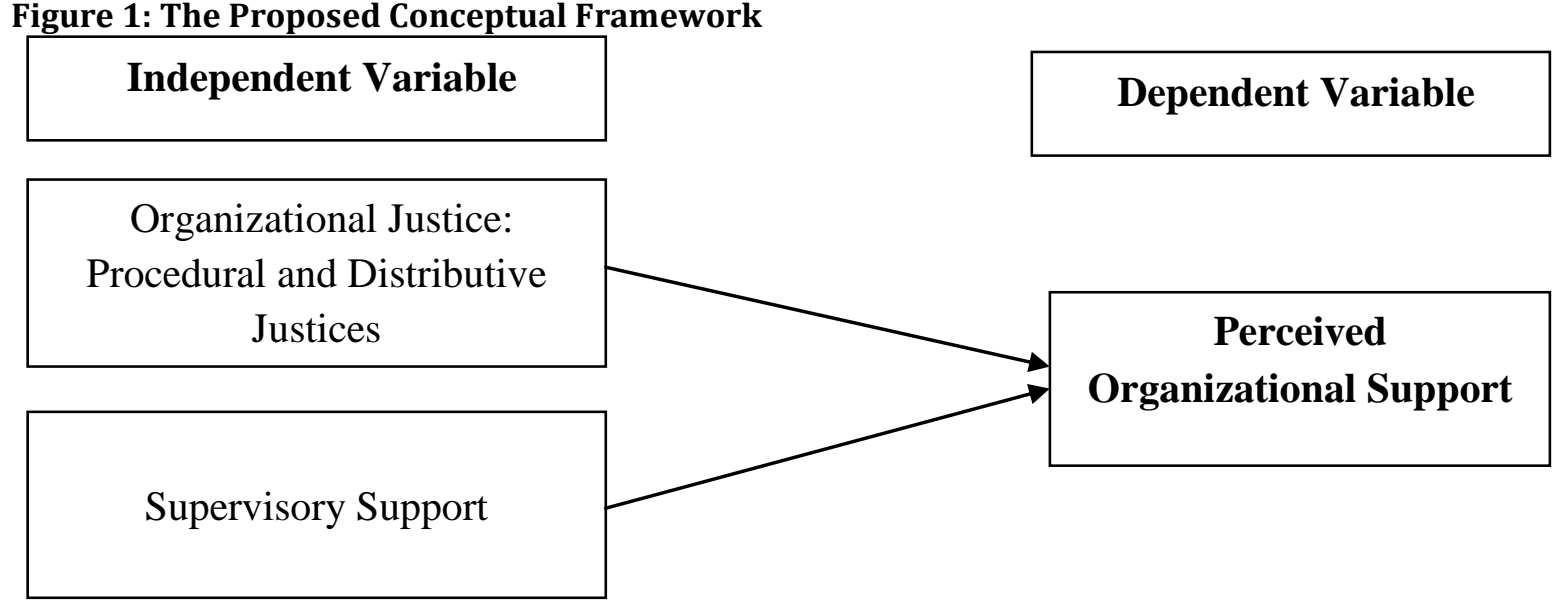

Sampling Design: The target population for this study involved academic staff of private universities located in Malaysia. Ten private universities were selected. All of the ten private universities were ranked tier 4 (good) and 5 (excellent) in SETARA 2012-2013. A proportionate stratified sampling technique was utilized. 
The purpose of using stratified sampling technique is to ensure that the respondents are heterogeneity in order to minimize common survey bias (Hair, Babin, Money \& Samouel, 2007).

Measurement: The measurement of Perceived Organizational Support was developed by Eisenberger, Huntington, Hutchison and Sowa (1986). This measurement consists of 36 items. There are 18 reverse scored items. Supervisory Support measurement was developed by and adapted from the same authors: Eisenberger, Huntington, Hutchison and Sowa (1986). This measurement consists of 12 items. For distributive justice and procedural justice, the measurements were adapted and developed by Price and Mueller's (1986) with six items and Niehoff and Moorman's (1993) with 6 items respectively. The measurement of Supervisory Support was adapted from Eisenberger et al. (2002) which consist of 12 items. Out of the 12 items, four items are used to measure the degree to which the supervisor care about their own subordinates well-being. The next four items focus on the extent to which the supervisors contribute to important organizational decision. The last four items examined the supervisor authority and autonomy toward their job responsibilities. All the measurements are using seven-point likert scale ranged from 1 representing "strongly disagree" to 7 representing "strongly agree".

Preliminary Study: A preliminary study has been conducted on two private universities. Total sample collected was 30 within one month. The sample consists of 17 female and 13 male respondents. Five respondents were associate professor, six respondents were senior lecturer and the remaining respondents were lecturers. The majority of respondents were Indian $(n=13)$. This is followed by Chinese $(n=10)$ and Malay (n=7). Nearly half of the respondents fall in the age group of 31 to 40 years old $(n=14)$. Only six qualified respondents have less than 2 years working experiences. Majority of the respondents were Master Degree Holder and only five respondents were $\mathrm{PhD}$ holder.

Reliability Analysis: Based on the results in table 1, the cronbach alpha value for all the variables are above 0.7 which has fulfilled the minimum value stated by Hair, Money, Samouel and Page (2007). Therefore, all of the variables reliability values are acceptable and considered reliable. The mean and standard deviation values for perceived organizational support $(M=3.9857, S D=0.55649)$, organizational justice $(M=4.4424$, $\mathrm{SD}=0.86697)$, procedural justice $(M=4.5778, S D=0.77278)$, distributive justice $(M=4.2800, S D=1.11739)$ and supervisory support $(\mathrm{M}=4.5083, \mathrm{SD}=0.99022)$ are displayed in the following table.

Table 1: Cronbach's Alpha Scores for Perceived Organizational Support, Organizational Justice, Procedural Justice, Distributive Justice and Supervisory Support

\begin{tabular}{llll}
\hline Variables & Cronbach's Alpha & Mean & Standard Deviations \\
\hline Perceived Organizational Support & 0.869 & 3.9857 & 0.55649 \\
Organizational Justice & 0.924 & 4.4424 & 0.86697 \\
Procedural Justice & 0.917 & 4.5778 & 0.77278 \\
Distributive Justice & 0.850 & 4.2800 & 1.11739 \\
Supervisory Support & 0.748 & 4.5083 & 0.99022 \\
\hline
\end{tabular}

\section{Conclusion}

The main objective for this study is to examine both the supervisory support and fairness of treatment or organizational treatment towards perceived organizational support among the academic staff in Malaysian private universities. The outcomes of this study are essential to all private universities in Malaysia as perceived organizational support plays an important role in universities in order to enhance the universities' performance. Past studies have confirmed the relationship and association between supervisory support and organizational justice with perceived organizational support in different context. Hence, this paper intends to empirically prove the hypothesized relationships with the proposed conceptual model in the Malaysian private universities context.

\section{References}

Allen, D. G., Shore, L. M. \& Griffeth, R. W. (2003). The role of perceived organizational support and supportive human resource practices in the turnover process. Journal of Management, 29(1), 99-118. 
Ambrose, M. L. \& Schminke, M. (2003). Organizational structure as a moderator of the relationship between procedural justice, interactional justice, perceived organizational support and supervisory trust. Journal of Applied Psychology, 88, 295-305.

Aquino, K. \& Griffeth, R. W. (1999). An exploration of the antecedents and consequences of perceived organizational support: a longitudinal study. University of Delaware and Georgia State University.

Byre, Z. S. \& Hochwarter, W. A. (2008). Perceived organizational support and performance: relationships across levels of performance cynicism. Journal of Managerial Psychology, 23(1), 54-72.

Colquitt, J. A., Conlon, D. E., Wesson, M. J., Porter, C. O. \& Ng, K. Y. (2001). Justice at the millennium: a meta analytic review of 25 years of organizational justice research. Journal of Applied Psychology, 86, 425445.

Cropanzano, R., Prehar, C. A. \& Chen, P. Y. (2002). Using social exchange theory to distinguish procedural from interactional justice. Group \& Organization Management, 27(3), 324-351.

Currie, P. \& Dollery, B. (2006). Organizational commitment and perceived organizational support in the NSW police. Policing: An International Journal of Police Strategies \& Management, 29(4), 741-756.

Dawley, D. D., Andrews, M. C. \& Bucklew, N. S. (2008). Mentoring, supervisory support, and perceived organizational support: what matters most? Leadership \& Organizational Development Journal, 29(3), 235-247.

Eisenberger, R., Armeli, S., Rexwinkel, B., Lynch, P. D. \& Rhoades, L. (2001). Reciprocation of perceived organizational support. 2001, 86(1), 42-51.

Eisenberger, R., Cummings, J., Armeli, S. \& Lynch, P. (1997). Perceived organizational support, discretionary treatment and job satisfaction. Journal of Applied Psychology, 82(5), 812-820.

Eisenberger, R., Huntington, R., Hutchison, S. \& Sowa, D. (1986). Perceived organizational support. Journal of Applied Psychology, 71(3), 500-507.

Eisenberger, R., Stinglhamber, F., Vandenberghe, C., Sucharski, I. L. \& Rhoades, L. (2002). Perceived organizational support: contributions to perceived organizational support and employee retention. Journal of Applied Psychology, 87(3), 565-573.

Folger, R. \& Cropanzano, R. (1998). Organizational justice and human resource management. Thousand Oaks, CA: Sage.

Gouldner, A. W. (1960). The norm of reciprocity: a preliminary statement. American Sociological Review, 25, 161-178.

Greenberg, J. (1987). A taxonomy of organizational justice theories. Academy of Management Review, 12(1), 922.

Greenberg, J. (1990). Organizational justice: yesterday, today, and tomorow. Journal of Management, 16, 399432.

Hair, J. F., Babin, B., Money, A. H. \& Samouel, P. (2007). Essential of business research methods. Chichester, West Sussex: John Wiley \& Son, Inc.

Lambert, E. (2003). Justice in corrections: an exploratory study of the impact of organizational justice on correctional staff. Journal of Criminal Justice, 31, 155-168.

Lambert, E. G., Hogan, N. L. \& Griffin, M. L. (2007). The impact of distributive and procedural justice on correctional staff job stress, job satisfaction, and organizational commitment. Journal of Criminal Justice, 35, 644-656.

Loi, R., Ngo, H. Y. \& Foley, S. (2006). Linking employees' justice perceptions to organizational commitment and intention to leave: The mediating role of perceived organizational support. Journal of Occupational Organizational Psychology, 79, 101-120.

Lynch, P. D., Eisenberger, R. \& Armeli, S. (1999). Perceived organizational support: inferior versus superior performance by Wary employees. Journal of Applied Psychology, 84(4), 467-483.

McShane, S. L. \& Von Glinow, M. A. (2010). Organizational behavior: emerging knowledge and practice for real world. (5th ed.). New York: McGraw-Hill/Irwin.

Nasurdin, A. M., Hemdi, M. A. \& Lye, P. G. (2008). Does perceived organizational support mediate the relationship between human resource management practices and organizational commitment? Asian Academy of Management Journal, 13(1), 15-36.

Niehoff, B. P. \& Moorman, R. H. (1993). Justice as mediator of the relationship between methods of monitoring and organizational citizenship behaviors. Academy of Management Journal, 36, 527-556. 
Pillai, R., William, E. S. \& Tan, J. J. (2001). Are the scales tipped in favor of procedural or distributive justice? An investigation of the U.S., India, Germany, and Hong Kong (China). International Journal of Conflict Management, 12, 312-332.

Price, J. L. \& Mueller, C. W. (1986). Handbook of organizational measurement. Masrhfield, MA: Pitman.

Rhoades, L. \& Eisenberger, R. (2002). Perceived organizational support: a review of the literature. Journal of Applied Psychology, 87(4), 698-714.

Rhoades, L., Eisenberger, R. \& Armeli, S. (2001). Affective commitment to the organization: the contribution of perceived organizational support. Journal of Applied Psychology, 86(5), 825-836.

Shanock, L. R. \& Eisenberger, R. (2006). When supervisors feel supported: relationships with subordinates' perceived supervisory support, perceived organizational support, and performance. Journal of Applied Psychology, 91(3), 689-695.

Shore, L. M. \& Shore, T. H. (1995). Perceived organizational support and organizational justice. In R. Cropanzano \& K. M. Kacmar (Eds.), Organizational politics, justice, and support: managing social climate at work.(pp. 149-164). Wesport, CT: Quorum Press.

Tan, F. M. (2008). Linking career development practices to turnover intention: the mediator of perceived organizational support. Journal of Business and Public Affairs, 2(1), 1-20.

Wayne, S. J., Shore, L. M., Bommer, W. H. \& Tetrick, L. E. (2002). The role of fair treatment and rewards in perceptions of organizational support and leader-member exchange. Journal of Applied Psychology, 87(3), 590-598. 